\title{
Belediye Başkanlarının Hizmet Yönelimli Liderlik Tarzları İle Şehir Yaşam Kalitesi Arasındaki İlişki
}

\author{
Dr. Öğr. Üyesi Nilüfer Rüzgar ${ }^{1^{*}}$ \\ Arș. Gör. Ahsen Nisa Odabaşoğlu ${ }^{2}$ \\ Dr. Öğr. Üyesi Bekir Özkan ${ }^{3}$
}

Geliş tarihi: 18.11.2019

Kabul tarihi: 06.12.2019

\section{Atıf bilgisi:}

IBAD Sosyal Bilimler Dergisi

Sayı: $5 \quad$ Sayfa: 598-614

Yıl: 2019 Dönem: Güz

This article was checked by iThenticate. Similarity Index 6\%

1 Bursa Teknik Üniversitesi, Türkiye nilüfer.rüzgar@btu.edu.tr,

ORCID ID 0000-0002-9598-3390

2 Bursa Teknik Üniversitesi, Türkive ahsen.odabasoglu@btu.edu.tr ORCID ID 0000-0002-6760-1180

3 Bursa Teknik Üniversitesi, Türkiye bekir.ozkan@btu.edu.tr

ORCID ID 0000-0001-5802-3473

* Sorumlu Yazar öz

Belediye başkanları, sundukları hizmetler vasıtasıyla kamu tarafindan bilinirlik kazanmaktadırlar. Bu bağlamda, hizmetkâr edasıyla hareket ederek "hizmetkâr lider" tarzını benimsemektedirler. Çalışanlarını ve hizmet verdiği kişilerle iletişimini daha şeffaf bir şekilde kuran, onlara destek sunan ve problemleriyle ilgilenen hizmetkâr liderlerin sunduğu hizmetlerin şehir yaşam kalitesi ile olan ilişkisi, vatandaşların başarılı yönetime dair fikirlerine etki etmesi beklenmektedir. $\mathrm{Bu}$ araştırmanın ana amacı, üniversite öğrencilerinin ikamet ettikleri yerde hizmet veren belediye başkanlarının benimsedikleri liderlik tarzına yönelik algılarının şehir yaşam kalitesine dair öz değerlendirmeleriyle olan ilişkisini ortaya çıkarmaktır. Bu amaca istinaden Yıldırım semtinde bulunan Bursa Teknik Üniversitesi'nde eğitimine devam eden 121 üniversite öğrencisine iki ölçekten oluşan bir anket uygulaması yapılmıştır. İlk ölçek, Demirel vd. (2012) tarafindan geliştirilen "Hizmetkâr Liderlik Ölçeğì"dir. İkinci ölçek ise Karamustafa, Güllü ve Acar (2010) tarafindan geliştirilen ve şehir yaşam kalitesini ölçmeyi amaçlayan "Önem-Performans Analizi Ölçeği”dir. Elde edilen veriler SPSS 22.0 paket programı kullanılarak analiz edilmiş, bu kapsamda da faktör analizi ve regresyon analizi yapılmıştır. Bulgulara göre hizmet yönelimli liderliğin şehir yaşam kalitesi üzerinde, özellikle Servis/Alçakgönüllülük boyutu bağlamında, istatistiksel olarak anlamlı bir etkisi bulunmaktadır. Bu nedenle, gelecekte farklı ilçeler, farklı şehirler ve farklı bölgeler üzerinde araştırmalar yapılması, Türkiye'nin genel bir çerçevesini çizme şansını verebilir. Böylelikle belediyelerin sunduğu hizmetlerde gerekli değişiklikler yapılarak vatandaşların şehir yaşamı kalitesi algıları olumlu yönde artabilir.

Anahtar Kelimeler: Belediye Başkanları, Liderlik Tarzı, Hizmetkâr Liderlik, Şehir Yaşam Kalitesi 


\title{
The Relationship between Mayors' Servant Leadership Styles and Quality of City Life
}

\author{
Assist. Prof. Dr. Nilüfer Rüzgar ${ }^{1 *}$ \\ Res. Assist. Ahsen Nisa Odabaşoğlu² \\ Assist. Prof. Dr. Bekir Özkan ${ }^{3}$
}

First received: 18.11 .2019

Accepted: 06.12.2019

\section{Citation: \\ IBAD Journal of Social Sciences \\ Issue: $5 \quad$ Pages: 598-614 \\ Year: $2019 \quad$ Session: Fall}

This article was checked by iThenticate. Similarity Index 6\%

1 Bursa Technical University, Turkey, nilüfer.rüzgar@btu.edu.tr,

ORCID ID 0000-0002-9598-3390

2 Bursa Technical University, Turkey, ahsen.odabasoglu@btu.edu.tr ORCID ID 0000-0002-6760-1180

3 Bursa Technical University, Turkey, bekir.ozkan@btu.edu.tr

ORCID ID 0000-0001-5802-3473

* Corresponding Author
ÖZ

Mayors are known by the public via the services they provide. Therefore, they act as servants and adopt "servant leadership" style. It is expected that the relationship between the services provided by servant leaders who build relationships with employees and the group that is served, who supports them and who take care of their problems, with quality of city life, shape the perceptions of citizens about successful management. In this study, the main purpose is to reveal the relationship between the perceptions of university students about their district of residence mayor's extent of displaying servant leadership qualifications and their self evaluations about quality of city life. With this purpose, a survey that consists two scales is applied to the 121 active students of Bursa Technical University, which is in Yildırım district, Bursa. The former scale is "Servant Leadership Scale" that is developed by Demirel et.al. (2012). The latter is "Importance-Performance Analysis Scale" that is developed by Karamustafa, Güllü and Acar (2010). The gathered data is analyzed via SPSS 22.0 package programme and factor analysis and regression analysis are applied. According to the findings, there is a statistically significant effect of servant leadership on quality of city life, especially in terms of Service/Humility dimensions. Therefore in the future, making researches on different districts, different cities and different regions can give the chance of drawing a general frame of Turkey. Thus, necessary amendments in the services that are provided by the municipalities would be done and the perceptions of citizens in terms of quality of city life can increase in a positive way.

Anahtar Kelimeler: Mayors, Leadership Styles, Servant Leadership, Quality of City Life 


\section{INTRODUCTION}

The term "Servant Leadership" was started to be used in Europe to define spiritual leaders such as fathers and nuns. The facts that spiritual leaders devote themselves to serve humanity, organize their management styles to provide peace, happiness and satisfaction of the community and give importance to spirituality more than materiality, were the main reasons of this term to arouse. In short, servant leadership first focuses on people and then focuses on the organization (Waddell, 2006, p.2).

Servant leadership concept is found appropriate for Turkish culture as well in terms of its qualifications. In Orhun Epigraphs, Bilge Kagan says “I haven't slept for the sake of Turkish people, I haven't sat down during the day and I have worked to the bitter end with my brother Kül Tigin. I have provided garments for my people in need, I have provided wealth for my people who suffer from poverty, I have raised the number of my people, I have established a community which is better than the other communities with powerful states and with powerful Khans" (Çelik, 2010, p.42). This statement of Bilge Kagan, points out that in Turkish culture serving and devoting is crucial. Hz. Muhammed's saying "The master of the nation, is the one who serve the nation", underlines this cruciality and puts emphasis on the religious side of Turkish management view. The saying "Serving the nation means serving Allah" can be evaluated as another proof of this point of view.

Quality of city life, on the other hand, is a concept that is developed upon the improvement of modern life and societies' becoming contemporary (Marans, 2007, p.299-352). Life quality, with a wider definition, is the general situation of life in terms of both individual and communal. Because of the fact that it has relationships with numerous fields such as philosophy, health, urban life etc., it has several definitions (Neal, Sirgy and Uysal, 1999, p.153-164). According to Von Kamp et.al (2003, p.5-18), life quality is accepted together with environment's measurable components such as spatial, physical and social in addition to perception styles of these components. Thus, the individuals' perceptions are evaluated via not only objective qualities but also subjective qualities.

In this context, the main purpose is to reveal the relationship between the perceptions of university students about mayor's, who manage the district that they reside, extent of displaying servant leadership qualifications and their self evaluations about quality of city life. With this purpose, a survey that consists two scales is applied to the 121 active students of Bursa Technical University, which is in Y1ldırım district of Bursa city. Although Yıldırım district is among the three biggest districts of Bursa city, the fact that it has been started to develop recently thanks to the university, makes the perceptions of the university students about the services of the municipality, even more important. The former scale is "Servant Leadership Scale" that is developed by Demirel et.al. (2012) by combining the scales of Dennis and Winston (2003) and Dennis and Bocarnea (2005), which are adapted into Turkish by Aslan and Özata (2011). The latter is "Importance-Performance Analysis Scale" that is developed by Karamustafa, Güllü and Acar (2010) in order to measure quality of city life as 42 items.

\section{SERVANT LEADERSHIP}

Servantship concept is based on "virtue theory", which consists of all spiritual values. Virtue theory, on the other hand, is a concept that is built on Aristotle's "ethics" and focuses on human rights (Patterson, 2003, p.6). According to Aristotle, ethics sheds light on the appropriate behaviours that ease people's lives in the community (Daly and Mattilla, 2007). From a wider perspective ethics; "is a system of standards, principles and moral values that define what is good and what is bad in individual and group relations and examines concepts such as good, bad, right and wrong" (Hatcher, 2004 cited in Rüzgar, 2017, p. 326).

Servant leadership theory has its source from Greenleaf's "Butler Theory" (Turhan, 2007, p. 30). In this context, the leader gives priority to the followers' needs and interests and therefore puts emphasis on moral principles and tries to build trust (Caldwell, Bischoff and Karri, 2002, p. 153-163). In this sense, the leader devotes himself/herself to the followers and aims at giving, not receiving (Pollard, 1996, p. 243).

Spears (2004, p. 10), points out that the effectivity of a leader in terms of servantship, cannot be 
determined by evaluating just the leader. Therefore the qualities of the followers such as being wise, autonomous and ready to serve, are important indicators of servant leadership.

In addition to afore mentioned qualities of servant leadership, these kind of leaders are altruists instead of being egoists. In this sense, they focus on fulfilling employees' needs, empowering them, and improving them individually (Laub, 1999, p. 308; Russell and Stone, 2002, p. 145-157; Greenleaf, 1977, p. 22; Stone, Russell and Patterson, 2004, p. 352). Therefore servant leadership requires paying attention to the followers all the time (Patterson, 2003, p. 6).

When the literature is scrutinized, ten main qualifications of servant leadership draw attention. These are; Latitudinarianism, which means drawing conclusions from past experiences in order to make decisions about future and being aware of today's reality. Listening to others, which stands for staying in touch with the followers and aiming at satisfying their needs. Taking responsibility of people's improvement, which stands for taking responsibility of individual, professional and spiritual improvement of the followers. Conceptualizing, which stands for thinking over the problems and conceptualizing each problem by handling them in a wholistic point of view. The power of persuasion, which means compromising with followers by persuading each individual about the changes in the environment, without being authoritative. Awareness, which means being aware of both his/her flaws and limitations and the flaws and limitations of the members of the followers. Management, which means protecting the resources of the organization and making fair distribution of these resources. Building communities, which means providing members of the organization with group activities that enables them feel better, improve themselves and make mutual sharing. Amendment, which stands for communicating with the followers individually in order to prevent negative feelings. Accepting and Empathy, which stand for empathizing in order to understand the current situations and the feelings of the followers (McDougle, 2009, p. 41-47; Beck, 2010, p. 7-17).

Laub (1999, p. 308), on the other hand, underlines six qualities of servant leadership as giving value to people, being trustworthy, delegating the duties, making teams like family, fulfilling the leadership needs of people and assuring individual improvement opportunities. Furthermore, in this frame he also developed a measure (Crippen, 2005, p.11-16).

\section{QUALITY OF CITY LIFE}

Quality, can be defined as a product that constitutes the standards and satisfies the expectations of the customers from the product. According to Turkish Language Constitution (Türk Dil Kurumu-TDK), "quality is the situation of a product that constitutes the best specifications" (TDK, 2019).

Although quality of city life, carries differences in great extent because of the fact that it is used in various concepts, in general terms it refers to the conditions of the environment such as weather and water pollution, inadequate housing etc., or to the individual qualities such as health condition and educational situation. In broad terms, it is related to the development of both economical and noneconomical social indicators because of the fact that they reflect societies' general health (Pacione, 1986, p. 1499).

According to Geray (1998, p. 327), quality of city life, which is also known as quality of urban life, reflects the fact of being superior to the pre-defined standards of the presentation extent of urban infrastructure, communication, transportation, housing etc. in spaces that are accepted as "cities" in terms of social, economical and spatial elements. In this sense, when the city carries the qualities that are superior to these pre-defined material standards, it is proved that the quality of life is in a good condition. In broader terms quality of city life consists social, cultural and political factors and processes. Individuals benefit from the opportunities that the city provides equally, balanced and in the frame of their needs. In addition they join to the educational, artistic and political activities and processes. In this sense, it seems necessary to consider quality of city life as multi-dimensioned. The extent of satisfying the societal needs that are specific to the city, is crucial in this context. The physical and material infrastructure, satisfying educational, artistic and cultural needs, contributing to the city management and supervising the management, joining the processes and making decisions related to defining societies' life style, are crucial in this sense. 
The cities that meet the mentioned criteria and that present a high quality of life, turn out to be attraction centers thanks to high qualified infrastructure, transportation services, security services, well-raised human resource and economical and technological accumilations (Yavuzçehre and Torlak, 2006, p. 203).

\section{PREVIOUS RESEARCHES}

When the related literature is scrutinized, studies on servant leadership is seem to be really scarce especially in international literature. Researches on quality of city life are scarce as well. Moreover, researches on the effect of servant leadership qualities of mayors on the quality of city life cannot be found. Therefore this study is expected to make a contribution to the literature in this context and lead other researchers to make studies and researches in other districts, other cities and other regions in order to draw a frame of the country in this sense. Furthermore, the results are expected to help applying necessary amandments both in municipalities and cities.

As an example for international researches in the context of servant leadership, Kent Keith in his website http, s.//toservefirst.com/definition-of-servant-leadership.html, first defines servant leadership and then explains the theory behind this leadership philosophy.

Spears (2013), who is the CEO of the Greenleaf Center for Servant-Leadership, points out the 10 gifts of a servant leader as well as a brief historical overview in his article in Daily Goods.

In his article titled, "What Does Leadership Look Like in the Future of Work", Forbes writer Jacob Morgan (2016) talked with the Group Chief Human Resources Officer of Tat, a group of over 100 companies and half a billion employees. The article explains why servant leadership may become more and more important in the following years in business life.

As for national researches on servant leadership, Aslan and Özata (2011) conducted a study on midwives, nurses and civil servants. They applied a survey that consists Dennis and Winston (2003) "Servant Leadership Scale" on 180 participants. According to the results, the item "My leader knows the aim and goal of the organization and he/she is aware of what he/she wants to achieve for the society" received the highest importance.

In another study, the population of the research is the mayors who are elected in 29 March 2009 elections. In this election 2903 mayors were elected in Turkey. The results of the elections were as such, s. AKP 1442 mayors $(\% 49,67)$, CHP 503 mayors $(\% 17,33)$, MHP 483 mayors $(\% 16,64)$, other parties 475 mayors $(\% 16,36)$. As the sample of the research 530 mayors, who accepted participating the research, are chosen. According to the results, no matter what kind of leadership style the mayors adopt, they do not display submissive roles. This means, they cannot be easily directed and manipulated by others. On the other hand, it doesn't mean that they never display submissive behaviour (Yörük and Dündar, 2011).

As for city-life quality researches, Türksever (2001), in her $\mathrm{PhD}$ dissertation conducted a research on İstanbul, Ankara, İzmir, Adana, Gaziantep and Antalya. His purpose was to reveal the factors that affect the quality and satisfaction of city life. Shee found that the effective factors are parks, green areas, health conditions and noise. Therefore she claims that in order to increase the quality of city life, these factors have to be improved.

In another study that is conducted by Weziak and Bialowolska (2016), 79 European cities were researched and the results indicate that satisfaction with city life varies considerably both inside cities and across Europe. They also found that lack of trustworthiness and efficiency of public administration contribute to dissatisfaction with life in the city.

Kaklauskas, Zavadskas, Radzeviciene, Ubarte, Podviezko, Podvezko, Kuzminske, Banaitis, Binkyte and Bucinskas (2018), conducted a research on European cities in order to find out if there are any differences among the indicators that measure quality of city life. According to the results, there is low sensitivity to differences between the methods under analysis. They also found out that INVAR method supplements Quality of Life Index technique with new functions and it provides quantitative guidelines for improving the quality of life (QL) in cities in addition to optimizing indicators by considering the existing QL situation in a city. 


\section{METHODOLOGY}

Quantitative methods emphasize objective measurements and the statistical, mathematical, or numerical analysis of data collected through polls, questionnaires, and surveys, or by manipulating pre-existing statistical data using computational techniques. Quantitative research focuses on gathering numerical data and generalizing it across groups of people or to explain a particular phenomenon (Babbie, 2010, p. 297).

The main problem and the hypothesis of the research focus on "what" and "to what extent" is the relationship between servant leadership and quality of city life. In addition, it is aimed to measure the general perception of the university students rather than individual perceptions. Therefore, in the light of all these information the method of the research is defined as quantitative method. As for data gathering, survey method is used. Some of the surveys are delivered via internet and some of the surveys are delivered as hardcopies. The city of Bursa, is a very rich city in terms of its historical roots. In addition, it is the 4. biggest city of Turkey. Therefore, the fact that it provides efficiency in reaching responds in terms of quality of city life, the main population of the research is defined as the university students that live in Bursa. However, it is impossible to reach the whole population because of the obstacles in terms of time and budget. In addition, Ylldirım district is a developing district as it is afore mentioned and the university students prefer to live around the university because of transportation convenience. Thus, unlike the students of Uludağ University, who prefer to live in developed Nilüfer district, it constitutes more importance to measure the perceptions of the students of Bursa Technical University.

Therefore, the research sample is defined as Ylldırım district, which is one of the three central districts. The main reason of this is the fact that although Ylldirm district is among the three biggest districts of Bursa city, it has been started to develop recently thanks to the university. In this sense, this makes the perceptions of the university students about the services of the municipality, even more important. As for sampling method, convenience sampling is used. The surveys are applied to the students of Bursa Technical University, which is in Yıldırım district of Bursa city; because of the fact that it enables convenience in terms of reaching the students who reside in Yildirim. 700 surveys are delivered to the university students via internet and as hardcopies and 121 responds are gathered. The gathered data is analysed via SPSS 22.0 package programme.

A survey that consists two scales and demographical questions is used. The former scale is "Servant Leadership Scale" that is developed by Demirel et.al. (2012) by combining the scales of Dennis and Winston (2003) and Dennis and Bocarnea (2005), which are adapted into Turkish by Aslan and Özata (2011). It has 32 items with seven dimensions labelled as Vision, Love, Humility, Trust, Service, Altruism and Empowerment. This combination is done in order to form a scale that is appropriate for measuring mayors' leadership qualities. Thus, an original measure has been contributed to the literature by the mentioned authors. In the current study, the items are gathered under two dimensions, different from the original scale. These dimensions are labelled according to items'relation with each other as Altruism/Love/Trust and Service/Humility. According to the reliability analysis of the scale, the cronbach's alpha value is 0,984 . The latter scale is "Importance-Performance Analysis Scale" that aims at measuring quality of city life in Kayseri and it is developed by Karamustafa, Güllü and Acar (2010). It has 42 items. The items are not gathered under any dimensions in the original scale; therefore a factor analyses is applied and it has been found that the items gather under five dimensions. Each dimension is labelled according to the items' relations with each other as Transportation/Comfort, Social Life, Open Spaces/Cleanness, Security/Facility Availability and Infrastructure. According to the reliability analyses the cronbach's alpha value is 0,983 . In addition, because of the fact that the original scale is developed in order to measure the quality of city life in Kayseri, the items are revised to be appropriate for Bursa.

\subsection{Hypotheses}

$\mathbf{H}_{\mathbf{0}}$ : There is no statistically significant difference between Servant Leadership and Quality of City Life.

$\mathbf{H}_{1}$ : Servant Leadership has statistically significant effect on Transportation and Comfort. $h_{1}: \mu_{1}>\mu_{2}$

$\mathbf{H}_{2}$ : Servant Leadership has statistically significant effect on Social Life. $h_{2}: \mu_{1}>\mu_{2}$

$\mathbf{H}_{3}$ : Servant Leadership has statistically significant effect on Open Spaces and Cleanness. $h_{3}: \mu_{1}>\mu_{2}$ 
$\mathbf{H}_{4}$ : Servant Leadership has statistically significant effect on Security and Facility Availability. $h_{4}: \mu_{1}>\mu_{2}$

$H_{5}$ : Servant Leadership has statistically significant effect on Infrastructure. $h_{5}: \mu_{1}>\mu_{2}$

\section{RESULTS}

\subsection{Demographical Findings And Dispersion Of Frequencies}

According to the demographical findings, $72(\% 59,5)$ participants are female and $49(\% 40,5)$ participants are male. As for age groups, $144(\% 67,9)$ participants are among 18-29, $50(\% 23,6)$ participants are among 30-39, $12(\% 5,7)$ participants are among 40-49 and $6(\% 2,8)$ participants are among 50-59 age groups. $1(\% 0,8)$ participants are married and $120(\% 99,2)$ participants are single.

\subsection{Reliability Analysis}

The cronbach's alpha value of Servant Leadership Scale has been found as 0,986 and the cronbach's alpha value of Importance-Performance Analysis Scale has been found as 0,980 (Table 1).

Table 1. Cronbach's Alpha Values of the Scales

\begin{tabular}{lll}
\hline Scale & Cronbach's Alpha Value & Number of Items \\
\hline Servant Leadership &, 984 & 32 \\
Importance-Performance Scale &, 983 & 42 \\
\hline
\end{tabular}

\subsection{Factor Analysis}

According to factor analyses (Table 2), Servant Leadership has two dimensions (Altruism/Trust/Love and Service/Humility), whereas the original scale has seven dimensions as afore mentioned. Altruism/Trust/Love dimension, explains Servant Leadership with a percantage of 40,221 and Service/Humility dimension with a percentage of $\% 31,490$. The cumulative percentage of all dimensions is $\% 71,712$.

Table 2. Total Variance Explained

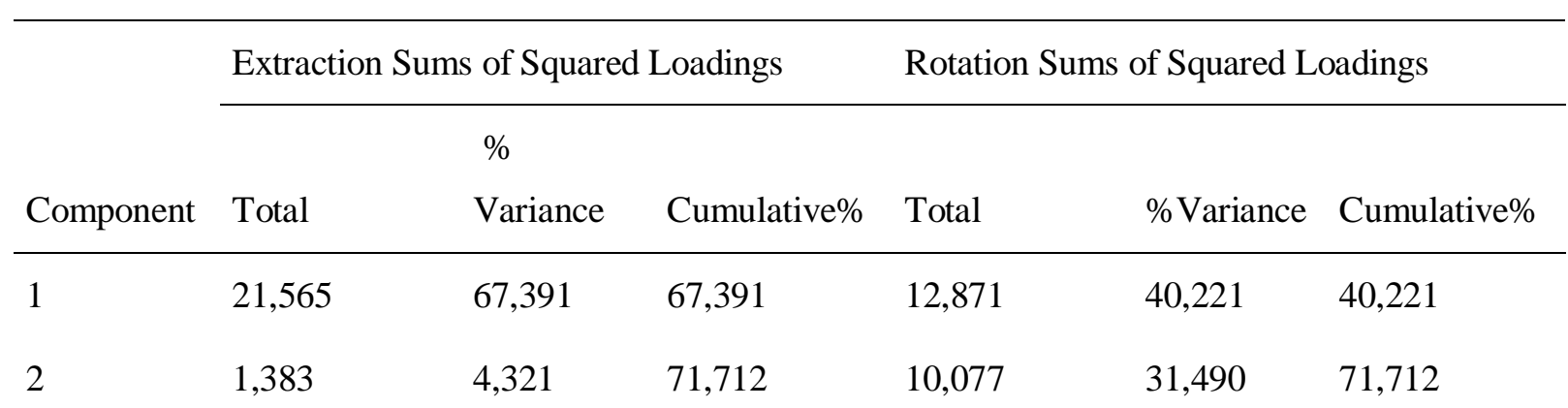

According to factor analyses (Table 3), Importance-Performance Analysis Scale has five dimensions. Because of the fact that the original scale is not classified under any dimensions, these dimensions are labelled as Transportation/Comfort, Social Life, Open Spaces/Cleanness, Security/Facility Availability and Infrastructure. Transportation/Comfort dimension, explains Importance-Performance Analysis Scale with a percantage of 20,884, Social Life dimension with \%16,958, Open Spaces/Cleanness dimension with \%14,859, Security/Facility Availability dimension with \%10,689 and Infrastructure dimension with $\% 9,619$. The cumulative percentage of all dimensions is $\% 73,008$. 
Table 3. Total Variance Explained

\begin{tabular}{lllllll}
\hline & \multicolumn{2}{l}{ Extraction Sums of Squared Loadings } & \multicolumn{2}{l}{ Rotation Sums of Squared Loadings } \\
\cline { 2 - 7 } Component & Total & \%Variance & Cumulative\% & Total & \%Variance & Cumulative\% \\
\hline 1 & 24,745 & 58,917 & 58,917 & 8,771 & 20,884 & 20,884 \\
2 & 2,063 & 4,912 & 63,830 & 7,122 & 16,958 & 37,842 \\
3 & 1,418 & 3,376 & 67,206 & 6,241 & 14,859 & 52,701 \\
4 & 1,295 & 3,083 & 70,288 & 4,489 & 10,689 & 63,390 \\
5 & 1,142 & 2,720 & 73,008 & 4,040 & 9,6119 & 73,008
\end{tabular}

\subsection{Regression Analysis Related To Hypothesis}

$\mathrm{H}_{1}$ : Servant Leadership has statistically significant effect on Transport/Comfort. $h_{1}: \mu_{1}>\mu_{2}$

According to the model summary table of this hypotheses (Table 4), it is seen that dependent variables Altruism/Trust/Love and Service/Humility have a regression value of $\% 58,8$ on Transport/Comfort.

Table 4. Model Summary

\begin{tabular}{lllllll}
\hline & & & & \multicolumn{2}{c}{ Adjusted } & Standart \\
Phase & $\mathrm{R}$ & $\mathrm{R}^{2}$ & $\mathrm{R}^{2}$ & Error \\
\hline 1 & & $, 767^{\mathrm{a}}, 588$ &, 581 & 8,15212 \\
\hline
\end{tabular}

a: adjusted

It is concluded from the ANOVA table of the model (Table 5) that at first phase the F value is statistically significant as $\mathrm{p}<.001 .\left(\mathrm{F}_{119-2}=29,917\right)$.

Table 5. ANOVA Values

\begin{tabular}{|c|c|c|c|c|c|c|}
\hline Phase & & $\begin{array}{l}\text { Sum of } \\
\text { Squares }\end{array}$ & $\mathrm{df}$ & Sum of Means & $\mathrm{F}$ & $\mathrm{p}$ \\
\hline \multirow[t]{3}{*}{1} & $\begin{array}{l}\text { Regression } \\
\text { Value }\end{array}$ & 1109,108 & 2 & 345,010 & 29,917 & ,000 \\
\hline & Residual & 7775,483 & 117 & 11,532 & & \\
\hline & Total & 18884,592 & 119 & & & \\
\hline
\end{tabular}

There is statistically significant effect of Service/Humility dimension of Servant Leadership on Transport/Comfort $(\mathrm{p}<, 01)$. So; if Altruism/Love/Trust increases 1 unit, Transport/Comfort quality increases ,858 unit. On the other hand, Altruism/Love/Trust dimension doesn't have statistically signiificant effect ( $p>, 01)$ on Transport/Comfort (Table 6).

Since Altruism/Love/Trust dimension doesn't have statistically significant effect, $\mathrm{h}_{1}$ : Servant Leadership has statistically significant effect on Transport/Comfort is partially accepted. 
Table 6. Coefficients

\begin{tabular}{|c|c|c|c|c|c|c|}
\hline \multirow[b]{3}{*}{ Phase } & & \multicolumn{2}{|c|}{$\begin{array}{l}\text { Unstandardised } \\
\text { Coefficients }\end{array}$} & \multirow[t]{2}{*}{$\begin{array}{l}\text { Standardised } \\
\text { Coefficients }\end{array}$} & \multirow[b]{3}{*}{$\mathrm{t}$} & \multirow[b]{3}{*}{$\mathrm{p}$} \\
\hline & & \multirow[b]{2}{*}{ B } & Standart & & & \\
\hline & & & Error & Beta & & \\
\hline \multirow[t]{3}{*}{1} & (Transport/Comfort) & 6,461 & 2,188 & & 2,953 &, 004 \\
\hline & Altruism/Love/Trust &,- 147 &, 178 &,- 104 &,- 827 & ,410 \\
\hline & Service/Humility &, 470 & ,069 &, 858 & 6,787 &, 000 \\
\hline
\end{tabular}

Dependent Variable: Transport/Comfort

$\mathrm{H}_{2}$ : Servant Leadership has statistically significant effect on Social Life. $h_{2}: \mu_{1}>\mu_{2}$

According to the model summary table of this hypotheses (Table 7), it is seen that dependent variables Altruism/Love/Trust and Service/Humility have a regression value of $\% 51,5$ on Social Life.

Table 7. Model Summary

\begin{tabular}{llllll}
\hline & & & \multicolumn{2}{c}{ Adjusted } \\
Phase & $\mathrm{R}$ & $\mathrm{R}^{2}$ & $\mathrm{R}^{2}$ & \multicolumn{2}{c}{$\begin{array}{l}\text { Standart } \\
\text { Error }\end{array}$} \\
\hline 1 & ,715 &, 515 &, 503 &, 81721 \\
\hline
\end{tabular}

a: adjusted

It is concluded from the ANOVA table of the model (Table 8) that at first phase the F value is statistically significant as $\mathrm{p}<.001 .\left(\mathrm{F}_{120-2}=61,749\right)$.

Table 8. ANOVA Values

\begin{tabular}{|c|c|c|c|c|c|c|}
\hline Phase & & $\begin{array}{l}\text { Sum of } \\
\text { Squares }\end{array}$ & $\mathrm{df}$ & Sum of Means & $\mathrm{F}$ & $\mathrm{p}$ \\
\hline \multirow[t]{3}{*}{1} & $\begin{array}{l}\text { Regression } \\
\text { Value }\end{array}$ & 4225,552 & 2 & 2112,776 & 61,749 &, 000 \\
\hline & Residual & 4037,423 & 118 & 34,215 & & \\
\hline & Total & 8262,975 & 120 & & & \\
\hline
\end{tabular}

Service/Humility dimension has statistically significant effect on Social Life $(p<, 01)$. So; if Service/Humility increases 1 unit, Social Life quality increases ,550 unit. On the other hand, there is no statistically significant effect ( $p>, 01)$ of Altruism/Trust/Love dimension of Servant Leadership on Social Life (Table 9).

Since Altruism/Love/Trust dimension doesn't have statistically significant effect, $\mathrm{h}_{2}$ : Servant Leadership has statistically significant effect on Social Life is partially accepted. 
Table 9. Coefficients

\begin{tabular}{|c|c|c|c|c|c|c|}
\hline \multirow[b]{3}{*}{ Phase } & & \multicolumn{2}{|c|}{$\begin{array}{l}\text { Unstandardised } \\
\text { Coefficients }\end{array}$} & \multirow[t]{2}{*}{$\begin{array}{l}\text { Standardised } \\
\text { Coefficients }\end{array}$} & \multirow[b]{3}{*}{$\mathrm{t}$} & \multirow[b]{3}{*}{$\mathrm{p}$} \\
\hline & & \multirow[b]{2}{*}{$\mathrm{B}$} & \multirow{2}{*}{\multicolumn{2}{|c|}{$\begin{array}{l}\text { Standart } \\
\text { Error }\end{array}$}} & & \\
\hline & & & & & & \\
\hline \multirow[t]{3}{*}{1} & (Social Life) & 7,031 & 1,559 & & 4,511 &, 000 \\
\hline & Altruism/Trust/Love &, 168 &, 127 &, 181 & 1,323 &, 188 \\
\hline & Service/Humility & , 199 &, 050 &, 550 & 4,020 &, 000 \\
\hline
\end{tabular}

Dependent Variable: Social Life

$\mathrm{H}_{3}$ : Servant Leadership has statistically significant effect on Open Spaces/Cleanness. $h_{3}: \mu_{1}>\mu_{2}$

According to the model summary table of this hypotheses (Table 10), it is seen that dependent variables VisAltruism/Trust/Love and Service/Humility have a regression value of \%64,6 on Open Spaces/Cleanness.

Table 10. Model Summary

\begin{tabular}{|c|c|c|c|c|}
\hline Phase & $\mathrm{R}$ & $\mathrm{R}^{2}$ & $\begin{array}{l}\text { Adjusted } \\
\mathrm{R}^{2}\end{array}$ & $\begin{array}{l}\text { Standart } \\
\text { Error }\end{array}$ \\
\hline 1 &, $804^{\mathrm{a}}$ & ,646 & ,640 & 5,29371 \\
\hline
\end{tabular}

a: adjusted

It is concluded from the ANOVA table of the model (Table 11) that at first phase the F value is statistically significant as $\mathrm{p}<.001 .\left(\mathrm{F}_{120-2}=107,800\right)$.

Table 11. ANOVA Values

\begin{tabular}{|c|c|c|c|c|c|c|}
\hline Phase & & $\begin{array}{l}\text { Sum of } \\
\text { Squares }\end{array}$ & $\mathrm{df}$ & Sum of Means & $\mathrm{F}$ & $\mathrm{p}$ \\
\hline \multirow[t]{3}{*}{1} & $\begin{array}{l}\text { Regression } \\
\text { Value }\end{array}$ & 6041,811 & 2 & 3020,905 & 107,800 & ,000 \\
\hline & Residual & 3306,751 & 118 & 28,023 & & \\
\hline & Total & 9348,562 & 120 & & & \\
\hline
\end{tabular}

Service/Humility dimension has statistically significant effect on Open Spaces/Cleanness ( $<<, 01)$. So, if Service/Humility increases 1 unit, Open Spaces/Cleanness quality increases ,638 unit. On the other hand, there is no statistically significant effect $(p>, 01)$ of Altruism/Trust/Love dimensions of Servant Leadership on Open Spaces/Cleanness (Table 12).

Since Altruism/Love/Trust dimension doesn't have statistically significant effect, $\mathrm{h}_{3}$ : Servant Leadership has statistically significant effect on Open Spaces/Cleanness is partially accepted. 
Table 12. Coefficients

\begin{tabular}{|c|c|c|c|c|c|c|}
\hline \multirow[b]{3}{*}{ Phase } & & \multicolumn{2}{|c|}{$\begin{array}{l}\text { Unstandardised } \\
\text { Coefficients }\end{array}$} & $\begin{array}{l}\text { Standardised } \\
\text { Coefficients }\end{array}$ & \multirow[b]{3}{*}{$\mathrm{t}$} & \multirow[b]{3}{*}{$\mathrm{p}$} \\
\hline & & \multirow[b]{2}{*}{$\mathrm{B}$} & \multicolumn{2}{|l|}{ Standart } & & \\
\hline & & & Error & Beta & & \\
\hline \multirow[t]{3}{*}{1} & $\begin{array}{l}\text { (Open } \\
\text { Spaces/Cleanness) }\end{array}$ & 3,417 & 1,411 & & 2,422 &, 017 \\
\hline & Altruism/Trust/Love &, 180 &, 115 &, 183 & , 1571 &, 119 \\
\hline & Service/Humility & ,246 &, 045 & ,638 &,- 203 &, 000 \\
\hline
\end{tabular}

Dependent Variable: Open Spaces/Cleanness

$\mathrm{H}_{4}$ : Servant Leadership has statistically significant effect on Security/Facility Availability. $h_{4}: \mu_{1}>\mu_{2}$

According to the model summary table of this hypotheses (Table 13), it is seen that dependent variables Altruism/Trust/Love and Service/Humility have a regression value of $\% 50,3$ on Security/Facility/Availability.

Table 13. Model Summary

\begin{tabular}{lllllll}
\hline & & & \multicolumn{3}{c}{ Adjusted } \\
Phase & R & $\mathrm{R}^{2}$ & $\mathrm{R}^{2}$ & \multicolumn{2}{c}{$\begin{array}{l}\text { Standart } \\
\text { Error }\end{array}$} \\
\hline 1 & &, $709^{\mathrm{a}}$ &, 503 &, 495 & 4,93198 \\
\hline
\end{tabular}

a: adjusted

It is concluded from the ANOVA table of the model (Table 14) that at first phase the F value is statistically significant as $\mathrm{p}<.001$. $\left(\mathrm{F}_{120-2}=59,726\right)$.

Table 14. ANOVA Values

\begin{tabular}{|c|c|c|c|c|c|c|}
\hline Phase & & $\begin{array}{l}\text { Sum of } \\
\text { Squares }\end{array}$ & df & Sum of Means & $\mathrm{F}$ & $\mathrm{p}$ \\
\hline \multirow[t]{3}{*}{1} & $\begin{array}{l}\text { Regression } \\
\text { Value }\end{array}$ & 2905,618 & 2 & 1452,809 & 59,726 &, 000 \\
\hline & Residual & 2870,283 & 118 & 24,324 & & \\
\hline & Total & 5775,901 & 120 & & & \\
\hline
\end{tabular}

Service/Humility dimension has statistically significant effect on Security/Facility Availability $(\mathrm{p}<, 01)$. So; if Service/Humility increases 1 unit, Security/Facility Availability quality increases ,706 unit. On the other hand, there is no statistically significant effect $(p>, 01)$ of Altruism/Trust/Love dimension of Servant Leadership on Security/Facility Availability (Table 15).

Since Altruism/Love/Trust dimension doesn't have statistically significant effect, $\mathrm{h}_{4}$ : Servant Leadership has statistically significant effect on Security/Facility Availability is partially accepted. 
Table 15. Coefficients

\begin{tabular}{|c|c|c|c|c|c|c|}
\hline \multirow[b]{3}{*}{ Phase } & & \multicolumn{2}{|c|}{$\begin{array}{l}\text { Unstandardised } \\
\text { Coefficients }\end{array}$} & \multicolumn{2}{|c|}{$\begin{array}{l}\text { Standardised } \\
\text { Coefficients }\end{array}$} & \multirow[b]{3}{*}{$\mathrm{p}$} \\
\hline & & \multirow[b]{2}{*}{ B } & \multicolumn{2}{|c|}{ Standart } & \multirow[b]{2}{*}{$\mathrm{t}$} & \\
\hline & & & Error & Beta & & \\
\hline \multirow[t]{3}{*}{1} & $\begin{array}{l}\text { (Security/Facility } \\
\text { Availability) }\end{array}$ & 6,276 & 1,314 & & 4,776 &, 000 \\
\hline & Altruism/Trust/Love &, 003 &, 107 &, 003 &, 024 & ,981 \\
\hline & Service/Humility &, 214 &, 042 & ,706 & 5,118 &, 000 \\
\hline
\end{tabular}

Dependent Variable: Security/Facility Availability

$\mathrm{H}_{5}$ : Servant Leadership has statistically significant effect on Infrastructure. $h_{5}: \mu_{1}>\mu_{2}$

According to the model summary table of this hypotheses (Table 16), it is seen that dependent variables Altruism/Trust/Love have a regression value of \%61,1 on Infrastructure.

Table 16. Model Summary

\begin{tabular}{lllllll}
\hline & & & & \multicolumn{2}{c}{ Adjusted } \\
Phase & $\mathrm{R}$ & $\mathrm{R}^{2}$ & $\mathrm{R}^{2}$ & $\begin{array}{l}\text { Standart } \\
\text { Error }\end{array}$ \\
\hline 1 & & $, 781^{\mathrm{a}}, 611$ &, 604 & 3,36360 \\
\hline
\end{tabular}

a: adjusted

It is concluded from the ANOVA table of the model (Table 17) that at first phase the F value is statistically significant as $\mathrm{p}<.001 .\left(\mathrm{F}_{120-2}=92,548\right)$.

Table 17. ANOVA Values

\begin{tabular}{|c|c|c|c|c|c|c|}
\hline Phase & & $\begin{array}{l}\text { Sum of } \\
\text { Squares }\end{array}$ & df & Sum of Means & $\mathrm{F}$ & $\mathrm{p}$ \\
\hline \multirow[t]{3}{*}{1} & $\begin{array}{l}\text { Regression } \\
\text { Values }\end{array}$ & 2094,142 & 2 & 1047,071 & 92,548 & ,000 \\
\hline & Residual & 1335,031 & 118 & 11,314 & & \\
\hline & Total & 3429,174 & 120 & & & \\
\hline
\end{tabular}

Service/Humility dimension has statistically significant effect on Infrastructure ( $p<, 01)$. So; if Service/Humility increases 1 unit, Infrastructure quality increases ,840 unit. On the other hand, there is no statistically significant effect $(\mathrm{p}>, 01)$ of Altruism/Trust/Love dimensions of Servant Leadership on Infrastructure (Table 18).

Since Altruism/Love/Trust dimension doesn't have statistically significant effect, $\mathrm{h}_{5}$ : Servant Leadership has statistically significant effect on Infrastructure is partially accepted. 
Tablo 18. Coefficients

\begin{tabular}{|c|c|c|c|c|c|c|}
\hline \multirow[b]{3}{*}{ Phase } & & \multicolumn{2}{|c|}{$\begin{array}{l}\text { Unstandardised } \\
\text { Coefficients }\end{array}$} & \multirow[t]{2}{*}{$\begin{array}{l}\text { Standardised } \\
\text { Coefficients }\end{array}$} & \multirow[b]{3}{*}{$\mathrm{t}$} & \multirow[b]{3}{*}{$\mathrm{p}$} \\
\hline & & \multirow[b]{2}{*}{ B } & Standart & & & \\
\hline & & & Error & Beta & & \\
\hline \multirow[t]{3}{*}{1} & (Infrastructure) & 2,853 & ,896 & & 3,184 &, 002 \\
\hline & Altruism/Trust/Love &,- 040 &, 073 &,- 067 &,- 545 &, 587 \\
\hline & Service/Humility & ,196 & ,028 &, 840 & 6,873 & ,000 \\
\hline
\end{tabular}

Dependent Variable: Infrastructure

\section{CONCLUSION AND DISCUSSION}

Servant leadership has been in our lives since it emerged as a modern movement 40 years ago. Leaders that aim at adapting the changes in both internal and external environments, evaluate servant leadership style as revolutionary in this sense and try to display related behaviours in order to assure peace, motivation, satisfaction and harmony. Patterson (2003), defines servant leaders as people who are altruists, trustworthy and who lead the followers with love, act with humility and empower the followers.

Quality of city life is an important indicator for citizens to be satisfied with the conditions of their residential area. In this sense, the quality of services that are provided by the municipalities via the mayors, play crucial roles. According to ServQual model, which means Service Quality, if the expected service level is higher than received service level, it means that service is unsatisfactory. When expected service level is equal to the received service level, it means that the service is satisfactory. In order to accept the perceived quality as ideal quality, it is essential that expected service should be lower than perceived service (Parasuraman, Zeithaml and Berry, 1994, p. 111-124).

In this context, the main purpose is to reveal the relationship between the perceptions of university students about their district of residence mayor's extent of displaying servant leadership qualifications and their self evaluations about quality of city life. According to the findings, there is statistically significant effect of Servant Leadership on Quality of City Life. On the other hand, in terms of subdimensions of both scales, there are some differences. For instance; Service/Humility dimension has statistically significant effect on Quality of City Life as whole. When Service/Humility increases, the Quality of City Life increases as well. This means Service/Humility effects Quality of City Life in a positive way. On the other hand, Altruism/Trust/Love dimension doesn't have statistically significant effect on Quality of City Life. In this sense, it can be concluded that the students give importance first to services that are provided by the mayor via municipality, then to humility of mayors. Having good manners and devoting himself to the residents' welfare are the most important factors that raise the quality of city life. Instead It can be easily understood that the student residents prefer a mayor that devotes himself to the district, build good relationships with the public and thus, increase the quality of city life. Therefore, the fact that Altruism/Trust/Love doesn't have statistically significant effect on quality of city life, can be the reason of students' need of concrete services that are provided. Being altruist and full of love, are not satisfactory factors for increasing the quality of life from the point of view of students. As they are members of Generation Z, who easily tend to criticize every thing and who do not trust abstract data such as love feeling, they need concrete evidences in order to trust someone as a quality of their generation.

The university students' perceptions of quality of city life is a crucial subject in terms of its being among the most important indicators of mayors' leadership styles. In this sense, satisfaction with the conditions of the city/district that they reside, is affected in a positive or negative way. In both international and 
national literature the researches in this context, cannot be found. Therefore in the future making researches on different districts, different cities and different regions can give the chance of drawing a general frame of Turkey. Thus, necessary amendments in the services that are provided by the municipalities would be done and the perceptions of citizens in terms of quality of city life can increase in a positive way. According to the results of the analysis; municipalities or mayors may strengthen the relationship between leadership and quality of life, with modesty and primarily by providing concrete services. In other words, while giving priority to a leadership approach focused on the balance between expected and received / perceived service, they should not take on an identity that is disconnected or superior from the public. Even if it makes no sense in analysis, this should not mean that the abstract values are completely ignore

Acknowledgement: This research has been supported by Bursa Technical University Scientific Research Projects Coordination Unit. The project number is $18 \mathrm{~N} 25$.

\section{REFERENCES}

Akçı, Y. and Uluışık, Ö. (2016). Marka şehir oluşturma: şehirde oturanların değerlendirmeleri üzerine bir uygulama (Adıyaman Örneği). Mustafa Kemal Üniversitesi Sosyal Bilimler Enstitüsü Dergisi, 13(34).

Aslan, Ş. and Özata, M. (2011). Sağlık çalışanlarında hizmetkâr liderlik: Dennis-Winston ve DennisBocernea hizmetkâr liderlik ölçeklerinin geçerlik ve güvenilirlik araştırması. Yönetim ve Ekonomi, 18(1),139-154.

Avcılar, M. Y. and Kara, E. (2015). Şehir markası kavramı ve marka şehir yaratma stratejilerine yönelik literatür incelemesi. Sosyal ve Beşeri Bilimler Araştırmaları Dergisi, (34), 76-94.

Babbie, E. R. (2010). The practice of social research. 12th ed. Belmont, CA: Wadsworth Cengage, 2010; Muijs, Daniel içinde, Doing quantitative research in education with SPSS. 2nd edition. London: SAGE Publications.

Beck, C. D. (2010). Antecedents of servant leadership: a mixed methods study. Unpublished Phd Dissertation. University of Nebraska, Lincoln.

Caldwell, C., Bischoff, S.J. and Karri, R. (2002). The four umpires: a paradigm for ethical leadership. Journal of Business Ethics, 36(1/2), 153-163.

Carr, A. J.,Gibson, B. and Robinson, P.G. (2001). Is quality of life determined by expectations or experience? BMJ, 322(7296), 1240-1243.

Cop, R. and Akpınar, İ. (2014). Öğrencilerin şehirlerin markalaşmasına yönelik algıları. Marmara Üniversitesi, İ.̇.B. Dergisi, 36(1), 69-88.

Crippen, C. (2005). Servant-leadership as a effective model for educational leadership and management: first to serve, then to lead. Management in Education, 18(5), 11-16.

Çelik, H. S. (2010). Kutadgubilig'de halk devlet ilişkileri: karşılaştırmalı bir bakış. Türk Dünyası Araştırmaları, 188, 37-50.

Daly, S. P. and Mattilla, M. (2007). Darwin and ethics: using natural selection to understand ethical business and organizational behavior. EJBO: Journal of Business Ethics and Organization Studies, 12(2). Retrieved on 2 August 2018 from http://ejbo.jyu.fi/articles/0501_1.html.

Demirel, E., Yatkın, A., Düşükcan, M., Derin, N., Çakınberk, A. and Güven, M. (2012). Yerel siyasetin liderleri olan belediye başkanlarına yönelik hizmetkâr liderlik ölçeği uyarlama çalışması. Akademik Yaklaşımlar Dergisi (Journal Of Academic Approaches), 3(2), 67-83

Dennis, R. (2004). Servant leadership theory: development of the servant leadership assessment instrument. Unpublished PhD Thesis. Regent University, Virginia Beach, Virginia, USA. 
Dennis, R.S. and Bocernea, M. (2005). Development of the servant leadership assessment instrument. Leadership and Organization Development Journal, 26(8), 600-615.

Dennis, R. and Winston, B. E. (2003). A factor analysis of page and wong's servant leadership instrument. Leadership and Organization Development Journal, 24(8), 455-459.

Deffner, A. and Lioruris, C. (2005). City marketing: a significant planning tool for urban develeopment in a globalised economy. 45th Congress of the European Regional Science Association. Vrije Universty, Amsterdam.

Farling, M. L. Stone, A.G. and Winston, B.E. (1999). Servant leadership: setting the stage for empirical work. Journal of Leadership Studies, 6(1-2), 50-72.

Geray, C. (1998). Kentsel yaşam kalitesi ve belediyeler. Türk İdare Dergisi, 70(421), 326-341.

Görün, M. and Kara, M. (2010). Kentsel dönüşüm ve sosyal girişimcilik bağlamında Türkiye'de kentsel yaşam kalitesinin artırılması. Yönetim Bilimleri Dergisi, 8(2), 139-164

Greenleaf, R. K. (1970). Center for servant leadership. What is servant leadership? Retrieved On 03 October 2018 from http://www.greenleaf.org/whatissl/index.html

Hatcher, T. (2004). A rationale for HRD-ethics and its inclusion as a theorotical foundatiton. Academy of Human Resource Development International Research Conference Proceedings. 272-286, Austin, TX

Huang, C., Oh, K., Zhang, Q. and Choi, Y. J. (2013). Understanding the city brand in the regional tourism market among college students. Journal of Travel and Tourism Marketing, 30(7), 662671.

Kaklauskas, A., Zavadskas, E. K., Radzeviciene, A., Ubarte, I., Podviezko, A., Podvezko, V., Kuzminske, A., Banaitis, A., Binkyte, A. and Bucinskas, V. (2018). Quality of city life multiple criteria analysis. Science Direct, 72, 82-93.

Karamustafa, K., Güllü, K. and Acar, N. (2010). Kayseri'nin pazarlanabilirliğinin şehir yaşam kalitesi açısından önem-başarım analizi ile değerlendirilmesi. Pazarlama ve Pazarlama Araştırmaları Dergisi, 3(05), 1-26.

Karmowska, J. (2002). Cultural heritage as an element of marketing strategy in european historic cities. Proceedings of the 5th European Commission Conference-Cultural Heritage Research: A PanEuropean Challenge, Luxembourg, 139-141.

Kotler P., Rein I. and Haider H.D. (1993), Marketing places: attracting investment, industry, and tourism to cities, Regions And Nations. New York: Macmillan.

Laub, J. (1999). Assessing the servant organization: development of the servant organizational leadership (SOLA) instrument. Dissertation Abstracts International, 60(02), 308.

Marans, R. (2007). Quality of life studies and their contributions to housing and policy. Gazimagusa Municipality Seminars, 26 March 2007, Gazimagusa.

Mcdougle, L. R. (2009). Servant leadership in higher education: an analysis of the perceptions of higher education employees regarding servant leadership practises at varying types of institutions. Unpublished PhD dissertation. University of Texas, San Antonio.

Morgan J. (2016). What does leadership look like in the future of work. Retrieved on 28 March 2019 from https://www.forbes.com/sites/jacobmorgan/2016/03/28/what-does-leadership-look-like-inthe-future-of-work/\#2b3381cd2704.

Neal, J. D., Sirgy, J. M. and Uysal, M. (1999). The role of satisfaction with leisure travel/tourism services and experiences in satisfaction with leisure life and overall life. Journal of Business Research, 44(3), 153-164.

O’toole, J. (1999). Leadership A to Z, a guide for the appropriately ambitious._San Fransisco: Jossey Bass. 
Pacione, M. (1986). Quality of life in glasgow: an applied geographical analysis. Environment and Planning A: Economy and Space, 18(11), 1499-1520. Retrieved on 12 May 2019 from https://doi.org/10.1068/a181499.

Parasuraman, A., Zeithaml, V. A. and Berry, L. L. (1994). Reassessment of expectations as a comparison standard in measuring service quality: implications for further research. Journal of Marketing, 58(1), 111-124.

Patterson, K. A. (2003). Servant leadership: a theoretical model. Unpublished Doctoral Dissertation. Regent University, London.

Pollard, C. W. (1996). The leader who serves. In F. Hesselbein, M. Goldsmith, and R. Beckhard (Ed.s). The leaders of the future: The Drucker Foundation. San Francisco: Jossey-Bass. 241-248.

Russell, R.F. and Stone, A. G. (2002). A review of servant leadership attributes: developing a practical model. LeadershipandOrganization Development Journal, (23), 145-157.

Rüzgar, N. (2017). A research on the perception of citizens regarding their mayors' apprehension of servant leadership: a research in the city of Bursa. 3rd International Conference on the Changing World and Social Research. Rome, Italy. 8-10 August.

Spears, L.C. (2004). Practing servant-leadership, Leader to Leade, 34, 7-11. Retrieved on 21 April 2019 from

http://www.viterbo.edu/uploadedFiles/academics/msl/PracticingServantLeadershipbyLarrySpear s.pdf.

Spears, L.C. (2004). The 10 Gifts of a Servant Leader. Retrieved on 26 March 2019 from http://www.dailygood.org/story/447/the-10-gifts-of-a-servant-leader-larry-spears/.

Stone, G. A., Russell, F. R. and Patterson, K. (2004). Transformational versus servant leadership: a difference in leader focus. Leadership and Organizational Development Journal, 25(4), 349361.

TDK (Türk Dil Kurumu). Büyük Türkçe Sözlük. Retrieved on 26 February 2019 from http://www.tdk.gov.tr/index.php?option=com_btsandarama=kelimeandguid=TDK.GTS.5c70463 9a4e536.95250796.

Turgut Y. H. (2007). Kentsel yaşam kalitesi: kuram politika ve uygulamalar. Mimarlık Dergisi. Sayı 335. $\begin{array}{llllll}\text { Retrieved } & \text { on } & 28 & \text { February } & 2018 & \text { from }\end{array}$ http://www.mimarlikdergisi.com/index.cfm?sayfa=mimarlikandDergiSayi=53andRecID=1325.

Turhan, M. (2007). Genel ve mesleki lise yöneticilerinin etiksel liderlik davranışlarının okullardaki sosyal adalet üzerindeki etkisi. Frrat Üniversitesi, Sosyal Bilimler Enstitüsü, Unpublished PhD Thesis. Firat Üniversitesi, Elazı $\breve{g}$.

Türksever, N. (2001). Türkiye'de büyük şehir alanlarında yaşam kalitesinin değerlendirilmesine yönelik bir yöntem denemesi. 91-95. İstanbul Teknik Üniversitesi Fen Bilimleri Enstitüsü. PhD Thesis. İstanbul Teknik Üniversitesi, İstanbul.

Von Kamp, I., Leidelmeijer, K., Marsman, G. and De Hollander, A. (2003). Urban environmental quality and human well-being towards a conceptual framework and de-marcation of concepts: a literature study. Landscape and Urban Planning, 6, 5-18.

Waddell, J. T. (2006). Servent Leadership. Proceedings of the Servant Leadership Research. Retrieved $\begin{array}{lllll}\text { on } & 28 & \text { February } & 2019 & \text { from }\end{array}$ http://www.regent.edu/acad/sls/publications/conference_proceedings/servant_leadership_roundt able/2006/pdf/waddell.pdf.

Weziak-Bialowolska, D. (2016). Quality of life in cities-empirical evidence in comparative European perspective. Science Direct, 58, 87-96.

Yavuzçehre, P. S. and Torlak, S. E. (2006). Kentsel yaşam kalitesi ve belediyeler: Denizli Karşıyaka örneği. Süleyman Demirel Üniversitesi Sosyal Bilimler Enstitüsü Dergisi, (4), 184-207. 
Yörük, D. and Dündar, S. (2011). Türkiye'deki yerel yöneticilerin benimsedikleri liderlik tarzlarına göre boyun eğici davranışlarının incelenmesi. Atatürk Üniversitesi İktisadi Ve İdari Bilimler Dergisi. 25(1), 93-106

http://www.triumphstrategicconsulting.com/2017/07/26/servant-leader/. Retrieved on 21 February 2019 